\title{
Supremasi Hukum dalam Masyarakat Madani .
}

\section{(Perspektif Sejarah Hukum Islam)}

\author{
Akh. Minhaji
}

The process of civil society establishment requires some social prerequisites, namely the Law supremacy. The writer of this book tries to apply the egality and the inclucivism of Islamis Law to support the establishment of the democratic society based on the diversity and the humanity. Having religion as the fundamental factor of the Law supremacy will lead Indonesia to find the solution of the social and ecomic problems arising as a result of the social changes in the reformation process.

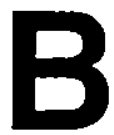

eberapa tahun terakhir, civil society yang seringkali diterjemahkan bahkan diidentikkan dengan istilah masyarakat madani telah menjadi sebuah wacana yang menarik perhatian hampir semua kalangan, utamanya kaum intelektual. Sejumlah karya telah muncul dan tulisan Muhammad AS Hikam,' Azyumardi Azra, ${ }^{2}$ dan Ahmad Baso nampaknya bisa memberikan bekal untuk menelusuri dan mengembangkan lebih jauh sejumlah pemikiran yang berkembang seputar civil society dan masyarakat madani. ${ }^{4}$

Namun patut pula dicatat, sejauh ini tulisan yang ada cenderung membahas civil society dan masyarakat madani secara umum, terutama terkait dengan fenomena politik, sosial, dan keagamaan atau berdasarkan disiplin masing-masing penulis; tidak satupun karya yang secara khusus dan mendalam mengkaji posisi hukum di tengah-tengah civil society atau masyarakat madani, dan lebih khusus lagi yang terkait dengan posisi hukum Islam dalam perspektif sejarah. ${ }^{5}$ Pendekatan sejarah ini perlu

'Muhammad AS Hikam, Demokrasi dan Civil Society (Jakarta: LP3ES, 1999).

2Azyumardi Azra, Menuju Masyarakat Madani (Bandung: Remaja Rosdakarya, 1999).

${ }^{3}$ Anmad Baso, Civil Society versus Masyarakat Madani (Bandung: Pustaka Hidayah. 1999).

'Baca pula kumpulan tulisan dalam Membangun Masyarakat Madani: Menuju Indonesia Baru Milenium Ketiga (Yogyakarta: Aditya Media, 1999); Louise Marlow, Hierarchy and Egalitarianism in Islamic Thought (Cambridge: Cambridge University Press, 1997).

'Dalam buku Membangun Masyarakat Madani, memàng terdapat satu Bab berjudul "Membangun Masyarakat Madani: Perspektif Hukum," namun isinya lebih menyangkut hukum umum bukan spesifik hukum Islam. 
digarisbawahi mengingat walaupun telah banyak karya-karya hukum Islam yang bernuansa sejarah, namun jarang ækali, untuk tidak mengatakan tidak ada, diantara kajian tersebut yang didukung oleh pengetahuan sejarah yang memadai. ${ }^{6} \mathrm{Me}$ nyadari itu semua, maka tulisan berikut dimaksudkan untuk mengisi kekosongan tersebut; namun sebelum masuk pada persoalan inti ada baiknya jika dibahas secara ringkas hubungan antara kedua istilah yang telah populer itu: civil society dan masyarakat madani.

\section{A. Antara Civil Society dan Masyarakat Madani}

Hingga kini pengertian civil society dan diskusi serta perdebatan menyangkut hal tersebut telah berkembang sedemikian rupa, bermula dari Aristoteles dan dilanjutkan oleh sarjana-sarjana berikutnya antara lain Cicero, Adam Ferguson, Johann Forster, Hegel, Karl Marx, Robert Mohl, JS Mills, Anne de Stael, dan Alexis de Tocqueville. Dan pengertian berikut nampaknya telah mewakili sekaligus menunjukkan pengertian yang cukup komprehensif (jami dan mani): "...wilayah-wilayah kehidupan sosial yang terorganisasi dan bercirikan, antara lain: kesukarelaan (voluntary), keswasembadaan (self-generating), dan keswadayaan (sell-supporting), kemandirian tinggi berhadapan dengan negara, dan keterikatan dengan norma-norma atau nilai-nilai hukum yang diikuti oleh warganya."

Pengertian di atas menunjukkan betapa penting posisi hukum di tengah-tengah civil society; tanpa hukum maka civil society hanya angan-angan belaka. Selanjutnya ditegaskan bahwa ciri utama civil society adalah: 1. adanya kemandirian yang cukup tinggi dari individu-individu dan kelompokkelompok dalam masyarakat, utamanya ketika berhadapan dengan negara, 2. ada- nya ruang publik bebas sebagai wahana bagi keterlibatan politik secara aktif dari warga negara melalui wacana dan praksis yang berkaitan dengan kepentingan publik, dan 3. adanya kemampuan membatasi kuasa negara agar ia tidak intervensionis.8. Secara lebih rinci Antonio Rosmi menyebut sepuluh ciri pokok: universalitas, supremasi, keabadian, pemerataan kekuatan, kebaikan dari dan untuk bersama, kebajikan individu, kebajikan umum, masyarakat eksternal, memberikan mantaat, masyarakat multikuota. ${ }^{9}$

Sejarah menunjukkan bahwa sebagai konsep yang tersusun secara sistematis, civil society berawal dan berkembang di kalangan masyarakat Barat dan kemudian menyebar ke wilayah-wilayah lain, termasuk wilayah yang masyarakatnya mayoritas beragama Islam seperti Indonesia. Walaupun pada mulanya umat Islam agak enggan menerima istilah civil society, ${ }^{10}$ namun lambat laun mereka semakin terbiasa dan upaya penerjemahan istilah tersebut kemudian dicoba dilakukan untuk disesuaikan dengan sejarah dan latar belakang mereka masingmasing. Masyarakat Islam Indonesia (dan juga Malaysia) kemudian mencoba menerjemahkan istilah civil society menjadi masyarakat madani (al-mujtama' al-madani), yang dipelopori antara lain oleh Anwar Ibra-

'Untuk masalah tersebut baca Akh. Mintraji. "Pendekatan Sejarah dalam Kajian Hukum Islam," Mukaddimah (lorthcoming, Januari 2000).

'Hikam, Civil Society, 3.

'Hikam, Civil Sociely, 219.

${ }^{9}$ Antonio Rosmini, The Philosophy of Rights, Rights in Civil Society (Durham: House. 1996), 28-50.

${ }^{10}$ Baso, Masyarakat Madani, 85. 
him dan Nurcholish Majid. " Saat ini istilah masyarakat madani hampir-hampir telah memasyarakat luas.

Tentu saja, terdapat sejumlah perbe daan prinsip antara kedua istilah tersebut, apalagi jika masyarakat madani dipahami sebagaimana tergambar pada masa awal Islam terutama masa Nabi di Madinah. Karena perbedaan prinsip itulah maka sebagian orang mencoba menerjemahkan civil society menjadi masyarakat sipil dan bukan masyarakat mádani. ${ }^{12}$

Seperti disinggung sebelumnya, sebagai sebuah konsep, civil society berawal dan berakar pada masyarakat Barat yang sekuler; yakni satu masyarakat yang pada dasarnya menempatkan agama not the only determinant factor dalam kehidupan manusia. Agama seringkali dipisahkan dari aspek-aspek kehidupan lainnya baik politik, ekonomi, sosial maupun budaya. Agama adalah urusan pribadi. Pemikiran yang demikian ditandai oleh lahirnya teori sejarah yang dikenal dengan providentia/ dan juga progressive, ${ }^{13}$ dan dilambangkan dengan ungkapan "a rendering unto Caesar that which is Caesar's and to God that which is God's." 14

Pandangan di atas jelas berbeda de ngan masyarakat madani, di mana agama menjadi satu-satunya faktor penentu kehidupan yang mencakup dan memayungi faktor-faktor kehidupan lainnya baik politik, ekonomi, budaya, máupun sosial. Karena

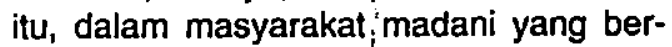
landaskan ajaran Islam, terutama masa klasik dan tengah, tidak mengenal, misalnya, pemisahan agama dengan politik atau agama dengan negara. Pemisahan demikian baru dikenal di kalangan masyarakat Islam pada masa modern, terutama setelah pengaruh pemikiran Barat yang ditandai dengan munculnya karya Ali Abdur Raziq, al-Isam wa Ushul al-Hukm, ${ }^{15}$ yang kemudian melahirkan kontroversi di kalangan para ulama baik yang semasa Raziq atau sesudahnya. Dilaporkan, misalnya, bahwa Rashid Ridla menolak pandangan Raziq seperti tercermin pada karyanya al-Khilafah aw al-Imamah al-Uzma' dan Yusr al-/slam wa Usul al-Tasyri' al-'Am. " Munculnya

"Komaruddin Hidayat, "Peran Agama dalam Penegakan Masyarakat Madani," Profetika 1 (1 Januari 1999), 99; idem, "Masyarakat Agama dan Agenda Penegakan Masyarakal Madani," dalam Membangun Masyarakat Madani, 267.

"2Muhammad AS Hikam, "Nahdlatul Ulama, Civil Society, dan Proyek Pencerahan." dalam Baso, Civil Society versus Masyarakat Madani, 11.

${ }^{13}$ Donald V. Gawronski, History: Meaning and Method (London: Acott, Foresman, and Company, 1969), 19-28; Jules R. Benyamin, A Student's Guide to History (New York: St. Martin's Press, 1994), 12-3.

14Stephen C. Hicks, "The Fuqaha and Islamic Law," American Joumal of Comparative Law 30 (1982), 2.

isEdisi terakhir dengan Kata Pengantar Muhammad Amarah diterbitkan pada tahun 1972 oleh al-Mu'assasah al- Arabiyyah di Beirut. Analisis sejarah terhadap fenomena dimaksud khususnya pada masa modern dapat dibaca pada Erwin I.J. Rosenthal, "Some Reflections on the Separation of Religion and Politics in Modern Islam," Islamic Studies 3 (1964), 249-84.

${ }^{16}$ Kairo: al-Mu'tamar al-Islami, 1923. Terjemahan dan sekaligus catatan-catatan penting dari buku ini bisa dibaca dalam Henri Laoust. Le Califat dans la doctrine de Rasid Rida (Kairo: al-Mu'tamar al-Islami, 1938).

"Kairo: al-Mu'tamar al-Islami, 1928. Analisa terhadap pemikiran Rashid Rida dalam buku ini dan juga buku sebelumnya bisa dibaca dalam Malcolm H. Kerr, Islamic Reform: The Political and Legal Theories of Muhammad Abduh and Rashid Rlda (Berkeley: University; of. Callfornia Press, 1966), terutama Bab V. "Muhammad Rashid Rida: A Revived Doctrine of Caliphate," 153-186; 
karya Khalid Muhammad Khalid, Min Huna Nabda'ı karya Muhammad al-Ghazali, Min Huna Na'lam, ${ }^{19}$ karya Sayyid Qutub, antara lain Hadha al-Din, Ma'alim fi al-Tariq dan al-'Adalah al-litima'iyyah fi al-lslam, ${ }^{20}$ Muhammad Sa'id al-Ashmawi dengan karyanya antara lain al-Islam al-Siyasi dan al-Khilafah al-Islamiyyah' dan Mustafa alSibba'i yang telah menjadikan Islam sebagai agama negara di Syria,2 semuanya merupakan diskusi lebih lanjut tentang perbedaan pendapat di kalangan sarjana Muslim menyangkut hubungan dan/atau pemisahan agama dengan negara dalam Islam.

Diakui, bahwa ada upaya-upaya sejum lah Orientalis yang mencoba menjustifikasi pemikir Islam modern yang membenarkan adanya kehidupan sekuler seperti terlihat pada pemisahan agama dengan politik atau agama dengan negara ${ }_{1}^{23}$ dengan mengatakan bahwa fenomena pemisahan demikian itu dikenal sejak masa awal Islam. Ini terlihat, antara lain, pada karya-karya Ira M. Lapidus, ${ }^{24}$ Tilman Nagel, ${ }^{25}$ Patricia Crone, dan Martin Hinds. ${ }^{26}$ Belakangan, karyakarya ini mendapat sanggahan keras dari seorang peneliti muda dari Quaid-i Azam University, Muhammad Qasim Zaman, yang menegaskan bahwa berdasarkan kajian ulang terhadap data sejarah awal Islam, pandangan bahwa Islam mengenal pemisahan agama dengan politik atau agama dengan negara tidak bisa lagi dipertahan kan. ${ }^{27}$ Hingga kini, karya Zaman ini belum mendapat respon balik dari mereka yang berpandangan adanya pemisahan agama dengan negara atau politik dalam Islam. Sebenarnya, jauh sebelum itu Muhammad Benaboud telah sampai kepada kesimpulan sejalan dengan pandangan Zaman dan menegaskan bahwa munculnya pemikiran tentang adanya pemisahan agama dengan negara, khususnya menyangkut abad Te ngah Islam di Andalusia, "pada umumnya merupakan pandangan-pandangan bias
Avriel Butovsky. The Language of History: Selected Writings on the Middle East (Cambridge: Harvard University Press, 1995).

${ }^{18}$ Kairo: Dar al-Nil al-Taba'at, 1950. Baca Fakhri, "Islamic State," 456, 459-62.

19Kairo: Dar al-Kitab al-'Arabi, 1951.

${ }^{20}$ Kairo, 1948. Catatan ringkas tentang karya tersebut dapat dibaca dalam Esposito dan Donohue, ed. Islam in Transition, terutama Bab II bagian "Sayyid Qutb: Social Justice in Islam," 123-8.

${ }^{2}$ Kedua karya tersebut di terbitkan di Kairo oleh Sina li-i-Nashr tahun 1990 dan 1992. Analisa terhadap pemikirannya dapat dibaca dalam Haddad, "Sayyid Qutb: Ideologue of Islamic Revival," dalam Voices of Resurgent Islam, ed. John L. Esposito (Oxford: Oxford University Press, 1983).

${ }^{22}$ Baca R. Bayly Winder, "Islam as the State Relion: A Muslim Brotherhood View in Syria," The Muslim World 44 (1954), 215-26.

${ }^{23}$ Pemikiran Orientalis untuk konteks Islam masa modern, baca Erwin I.J. Rosenthal, "Some Reflections on the Separation of Religion and Politics in Modern Islam," Islamic Studies 3 (1964), 249-84.

${ }^{24}$ Baca Ira M. Lapidus, "The Separation of State and Religion in the Development of Early Islamic Society." International Joumal of Middle East Studies 6 (1975), 363-85.

${ }^{25}$ Baca Tilman Nagel, Rechtleitung und Kalifat: Versuch uber eine Grundfrage der islamishen Geschichte (Bonn: Bonner orientalische Studien, 1975).

${ }^{26}$ Baca Patricia Crone dan Martin Hinds, God's Caliph: Religious Authority in the First Centuries of Islam (Cambridge: Cambridge University Press, 1986); Patricia Crone, Slaves on Horses: The Evolution of the Islamic Polity (Cambridge: Cambridge University Press. 1980).

${ }^{27}$ Muhammad Qasim Zaman, "The Caliph, The Ulama, and The Law: Defining the Role and Function of the Caliph in the Early 'Abbasid Period," Islamic Law and Society 4 (1997). 1-36. 
sejumlah Orientalis. "28 Saya kira hubungan antara agama dan negara dalam perspektif Islam telah digambarkan secara baik oleh Fazlur Rahman ketika mengatakan, bahwa politik bukanlah sesuatu yang berdiri sendiri dan terpisah dari agama, ia tidak lebih. dari sekedar sarana untuk menegakkan ajaran agama. Dalam bahasa Rahman sendiri:

The outline presented here should make clear the relationstip between 'religion' and 'state' under the Prophet. It is not the case that 'religion' dan 'state' were sisters; nor can it be said that they 'co-operated' with one another. Thestate is nothing at all by itself; it is a reflex of those moral and spiritual values and principles called Islam. The state is not an 'extension' of religion; it is an instrument of Islam, a stransparent instrument which vanishes when one tries to regard it per se. ${ }^{29}$.

Dengan demikian, pemikiran bähwa dalam Islam terdapat pandangan sekuler yang berwujud pada terpisahnya agama dengan negara masih amat kontroversial dan karena itu belum bisa meyakinkan sejumlah kalangan intelektual bahwa civil society yang berasal dari Barat yang sekuler adalah sama dan identik dengan masyarakat madani yang berorientasi pada masyarakat awal Islam. Namun demikian, dengan tidak menafikan perbedaan yang cukup dalam antara civil society dengan masyarakat madani, persamaán mendasar dapat pula ditemukan pada kedua konsep tersebut. Dan dalam konteks pembahasan kali ini, persamaan antara keduanya terletak pada posisi central dan pentingnya hukum bagi warganya. Kesamaan inilah yang antara lain menjustifikasi sejumlah kalangan yang mengidentikkan istilah civil society dengan masyarakat madani. Karena itu, pembahasan selanjutnya akan lebih difokuskan terutama pada supremasi hukum Islam di tengah-tengah masyarakat madani.

\section{B. Hukum Islam dan Masyarakat Madani}

Salah satu prinsip dalam Islam adalah: hukum bersifat divine (ilahiyyah) telah ada sebelum manusia, dan ditentukan oleh Allah sebagai pedornan bagi kéhidupan manusia.30 Prinsip' ini berbeda dengan hukum sekuler" yang menegaskan bahwa hukum itu dibuat oleh dan berasal dari masyarakat serta diperuntukkan bagi masyarakat yang bersangkutan. ${ }^{32}$

Dalam Islam hukum menempati posisi penting bahkan amat sentral, begitu sentralnya sehingga seringkali dikatakan bahwa Islam identik dengan hukum (Islam is the $(a w)^{33}$ atau Islam adalah agama hukum

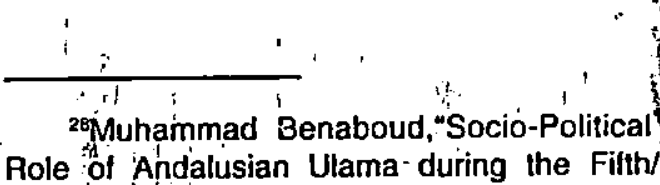
Eleventh Century," Islamic Studies 30 (1991). 182.

1. ${ }^{29} F$ alur Rahman, "Islam and Political ACtion: Pólitics in the Service of Religion," dalam Cities of Gód, 154.

${ }^{30}$ Seyyéd Hossein Nasr, The Shariah, Divine Law - Social and Humañ 'Norm," dalam ideals alnd Reálities of Islam (London: Allen \& Unwin, 1985).

"Untuk perbandingan tersëbut baca anItara'Iain Amin Átisán Islahi, Islamic Law: Concepl and ,Codification (Lahore: Islamic Publications, 1989); lérutama Bab 1, 11-12; J.N.D.

32Untuk gambaran masyarakat sekuler, baca Harvey, Cox, The Secular City (New' York: The Macmillan Company, 1965) dan diskusi atas materi buku tersebut dapat dibaca pada Daniel Callahan, ed. The Secular City Debate (New York: The Macmillan Company, 1966).

${ }^{33}$ Hicks, "Fuqaha and :Islamic Law," 2. 
(Islam is a religion of law). ${ }^{34}$ Pentingnya posisi hukum ini diperkuat dengan kandungan Piagam Madinah yang sarat dengan nuansa aturan-aturan yang harus dipatuhi oleh penduduk yang kemudian dikenal dengan konstitusi resmi Negeri Madinah di bawah kepemimpinan Nabi Muhammad SAW. Walaupun ada yang meragukan, ${ }^{35}$ namun sebagian besar meyakini bahwa Piagam Madinah ini merupakan konstitusi tertulis pertama dalam sejarah umat manusia yang sampai kepada kita. ${ }^{36}$

Banyak alasan kenapa posisi hukum dalam Islam amat penting, antara lain sebagaimana dikemukakan Sam'ani dalam kitabnya Qawati' al-Adillah. Seperti dilaporkan Makdisi:

Sam'ani memulai pembahasannya dengan mengatakan bahwa ilmu hukum Islam ( iim al-figh) adalah ilmu yang paling penting dalam Islam (the most noble of the scinces), sebab ilmu tersebut membahas peristiwa-peristiwa yang selalu muncul, berubah, berkembang dan tidak pernah berhenti serta tidak ada batasnya. Konsekuensinya, pengetahuan yang. dituntut untuk menangani persoalan tersebut juga tidak terbatas dan selalu menuntut pengembangan.

Ada konsekuensi lain dari prinsip di atas. Hukum seperti terelaborasi pada sumber pokok Islam, al-Qur'an, menuntut ketundukan dari semua pihak baik rakyat, penguasa, bahkan Nabi Muhammad sekalipun. Walaupun Sunnah Nabi pada masa berikutnya menjadi sumber pokok, tetapi kedudukannya menempati posisi kedua setelah al-Qur'an, dan hubungannya dengan alQur'an, sebagaimana dijelaskan oleh alSyatibi, lebih bersifat subordinate ketimbang complementary. Dengan demikian, Nabi Muhammad, yang secara sosial dan politik dapat dikatakan sebagai pimpinan tertinggi dalam pemerintahan Islam, juga harus tunduk dan patuh atas ketentuan- ketentuan hukum al-Qur'an. ${ }^{37}$ Ini berarti bahwa supremasi hukum merupakan sifat alami yang melekat dalam ajaran Islam dan harus ditegakkan untuk siapa saja termasuk para penguasa, bahkan Nabi sekalipun. Karena itu tidak berlebihan ketika Louise Marlow meneliti karya-karya Islam abad Tengah sampai kepada kesimpulan: "The scholarly outlook places great emphasis on the role of the divine law and the king's subservience to it." ${ }^{\text {"38 }}$

Sejarah juga menunjukkan bahwa supremasi hukum seperti dijelaskan di atas telah mampu melahirkan perubahan fundamental di kalangan masyarakat Arab ke-

${ }^{34 B a c a}$ C. Snouck Hurgronje, Selected Works of C. Snouck Hurgronje, ed. G.H. Bousquet dan Joseph Schacht (Leiden: E.J. Brill, 1957), 48; Joseph Schacht, "Theology and Law in Islam," dalam Theology and. Law in. Islam, ed. G.E. von Grunebaum (Wiesbaden: Otto Harrassowitz, 1971), 3-4.0

${ }^{35}$ Salah seorang yang secara tegas mengatakan bahwa dokumen tersebut adalah ash-Shahifah "bukan 'Konstitusi' atau 'Piagam"' adalah Ahmad Baso dalam karyanya Civil Society versus Masyarakat Madani, 331-51.

- ${ }^{36}$ Informasi dan analisa terhadap Piagam Madinah bisa dibaca; Ahmad Syafii Maarif, "Piagam Madinah dan Konvergensi Sosial," Pesantren 3 (1986), 12-21; Nourouzzaman Shiddiqi, Piagam Madinah (Yogyakarta: Mentari Masa, 1994); Ahmad Sukardja, Piagam Madinah dan Undang-Undang Dasar 1945 (Jakarta: UI Press, 1995).

${ }^{37} \mathrm{Nabi}$ sendiri mengakui bahwa suatu saat bisa saja ia melakukan kesalahan dan wahyu menjadi alat koreksi terhadap kesalahan itu: baca M.J. Kister, "Social and Religious Concepts of Authority in Islam," Jerusalem Studies in Arabic and Islam 18 (1994), 86.

${ }^{38}$ Louis Marlow, "Kings, Prophets, and the Ulama in Medieval Islamic Advice Literature," Studia Islamica 81 (1995), 111. 
tika itu dan merubah mereka yang semula terbelakang menjadi maju dan kosmopolit serta mampu memimpin peradaban dunia pada masanya.$^{39}$ Sayang masyarakat ideal demikian tidak mampu bertahan lama. Setelah Nabi wafat, hukum tidak lagi menjadi panglima; kepentingan pribadi, kelompok, maupun suku justru mengedepan. Barangkali tidak terlalu berlebihan ketika Robert N. Bellah mengatakan bahwa konsep yang ditawarkan Nabi itu amat modern bahkan terlalu modern untuk masanya sehingga tidak mampu dilanjutkan oleh masyarakat berikutnya. ${ }^{.0}$

Prinsip supremasi hukum yang menun tut ketundukan semua pihak diperkuat oleh prinsip berikutnya: hukum Islam merupakan jurists' law, lawyers' law, atau hukum para fuqaha. Itu berarti, hukum dalam Islam dirumuskan oleh para ulama yang pada masa awal Islam identik dengan fuqaha (religious authority) ${ }^{41}$ dan bukan oleh penguasa (political authority) yang belakangan cenderung bersifat korup guna mempertahankan kekuasaannya. Karena itu sejarah Islam klasik tidak pernah menunjukkan adanya hukum yang dirumuskan oleh penguasa. Rumusan hukum diserahkan kepada para fuqaha yang menempati posisi sentral lebih dari sekedar ahli hukum sebagaimana dipahami saat ini. Pada saat yang sama umat Islam diberi kebebasan untuk memilih salah satu dari sekian pendapat para fuqaha. Secara teori, prinsip ini melahirkan pandangan yang hakiki tentang sifat pluralis, egaliter, toleran, demokratis, dan sekaligus saling menghargai, yakni sifat-sifat yang seringkali dilambangkan dengan ungkapan yang dikatakan berasal dari Nabi ikhtilafu ummah rahmah (perbedaan merupakan rahmat) dan didukung pula oleh ayat alQur'an. ${ }^{42}$ Sifat-sifat yang mulia yang menjadi ciri masyarakat madani ini tergambar secara indah dalam kehidupan bermazhab di masa awal Islam, dimana setiap tokoh mazhab dan para pengikutnya menghargai pihak-pihak yang berbeda bahkan yang bertentangan sekalipun. ${ }^{43}$ Karena itu, perbedaan pendapat (kilafiyah) dan sikap toleran menjadi fenomena umum kalangan fuqaha dan juga para pengikutnya pada masa awal Islam.

Atas dasar pemikiran di atas, maka dapat dipahami bahwa ketika al-Mansur (Khalifah Abbasiyah), atas saran Ibn alMuqaffa', meminta Imam Malik (seorang faqih) untuk menjadikan kitab al-Muwatta'nya sebagai undang-undang resmi negara yang harus diikuti oleh semua warganya, Imam Malik menolak dengan alasan bahwa hal itu berarti tidak menghargai pendapat fuqaha lain yang berbeda dan dalam jangka panjang justru memasung kreatifitas berpikir umat Islam. ${ }^{44}$ Sejarah juga menunjukkan adanya sejumlah fuqaha dan mutti yang menolak tawaran sebagai hakim atau jabatan lainnya karena khawatir terkooptasi

39Moshe Sharon, Black Banners from the East (Leiden: E.J. Brill, 1983), 16, 19.

${ }^{40}$ Robert N. Bellah, Beyond Belief: Essays on Religion in a Post-Traditional World (New York: Harper \& Row Publishers, 1970).

"George Makdisi, "Tabaqat-Biography:

Law and Orthodoxy in Classical Islam," Islamic Studies 32 (1993), 374.

4Renungkan surah al-Hujurat ayat 13.

4Untuk diskusi mazhab, baca antara lain Abu Zahrah, Tarikh al-Madzahib al-Islamiyyah fi al-Siyasah wa al-Aqa'id wa Tarikh alMadzahib al-Fiqhiyyah (Kairo: Dar al-Fikr alArabi, 1963), terutama Bab 2, "Fi Tarikh alMadzahib al-Fiqhiyyah," 233ff.

"Islahi, "Concept and Codification," 8993; J.N.D. Anderson, "The Movement Towards Codification in Turkey, Cyprus and the Arab World," The Indian Year Book of Intermational Affairs (1958), 127; idem, "Codification in the Muslim World," Rebels Zeitschrill 30 (1966). 243; N.J. Coulson, A History of Islamic Law (Edinburgh: Edinburgh University Press, 1964), 52. 
oleh kekuasaan. ${ }^{45}$ Di sini, ilmu dan ilmuwan menempati posisi penting bahkan lebih penting dari kekuasaan dan penguasa politik. Pemikiran ini didukung oleh satu pemahaman bahwa Islam tidak mengenal clergy maupun priesthood sebagaimana dikenal pada agama-agama lain yang antara lain dilambangkan dengan kekuasaan gereja, sinod, councils, maupun sinagog; yakni satu konsep dimana umat tidak mempunyai kebebasan dalam memilih ketentuan hukum. ${ }^{46}$

Dengan demikian, kebebasan, pluralis, toleran, dan kreatif telah menjadi fenomena penting di tengah-tengah masyarakat Islam dan selanjutnya menjadi prinsip dalam sistem pendidikan yang menjadi sarana lahirnya para ilmuwan (fuqaha). Sebagai konsekuensinya, kebebasan akademik dan kebebasan mimbar yang menjadi sarana penting bagi generasi penerus merupakan sifat melekat dari perguruan tinggi Islam yang hal itu kemudian diadopsi oleh perguruan tinggi Barat melalui jalur perguruan tinggi pada masa kemajuan Islam di Spanyol, ${ }^{47}$ yang selanjutnya menjadi ciri penting perguruan tinggi modern. ${ }^{48} \mathrm{Hal}$ ini terlihat, misalnya, pada konsep ijazat altadris, licentia docendi, dan doctorate, yakni kewenangan mengajar. Semua ini, menurut Makdisi, menjadi ciri Islam dan berawal dari tradisi dan lingkaran studi hukum Islam yang dilambangkan melalui penganugerahan al-ijazah bi al-tadris wa al-ifta' (lisensi mengajar dan kewenangan memberi fatwa). Ini semua dicapai melalui satu proses perdebatan ilmiah (tariqat alnazar atau munazarah) secara terus me nerus. ${ }^{49}$

Diakui bahwa sikap pluralis, toleran, demokratis, dan kebebasan sebagaimana tergambar pada sifat alami kajian hukum Islam tersebut tidak selalu tenwujud dalam masyarakat Islam. Bahkan tidak jarang sifat kebebasan tersebut justru melahirkan sikap-sikap arogan baik pada level individu maupun kelompok; perbedaan seringkali diteruskan pada wujud permusuhan. Dalam konteks inilah bisa dipahami fanatisme mazhab dalam Islam (ta'assub). Pada level negara, terutama sejak masa-masa kemunduran Islam hingga sekarang, ada indikasi munculnya sikap centrifuga/sehingga sejumlah masyarakat Islam cenderung untuk saling memisàhkan diri (mis. Bangladesh dan Aceh) dan hal ini justru berbeda dengan negara-negara di Eropah yang justru cenderung menyatukan diri (centripeta).

Setelah mempertimbangkan bahwa hukum Islam itu adalah jurists' law, lawyers' law, atau hukum para fuqaha dan bukan hukum penguasa, maka tidak mengherankan jika ada sebagian sarjana yang berpendapat bahwa kodifikasi yang menjadi

${ }^{45}$ Noel James Coulson, "Doctrine and Practice in Islamic Law: One Aspect of the Problem," Bulletin of the School of Oriental and Alrican Studies 18 (1956), 211-2.

${ }^{46}$ Khalifa Abdul Hakim, "The Natural Law in the Mosiem Tradition," dalam University of Notre Dame Natural Law Institute Proceedings, ed. Edward F. Barrett (Indiana: University of Notre Dame, 1951), 54-5

${ }^{47}$ Makdisi, "Freedom in Islamic Jurisprudence," 79-88; idem, "Magisterium and Academic Freedom," 117-33.

${ }^{49}$ Contoh di atas merupakan satu bukti bahwa sejumlah pemikiran modern sekarang ini berasal dari pemikiran Islam. Contohcontoh lain bisa dibaca dalam Gustave Le Bon, The World of Islamic Civilization (Geneve: Editions Minerva, 1974), terutama Bab 12, "The Arab's Civilizing Influence on Europe," 137-ff. Khusus untuk pengaruh sistem hukum Islam terhadap sistem hukum lain dapat dibaca dalam Joseph Schacht, "Islamic Religious Law," dalam The Legacy of Islam, ed. Joseph Schacht dan C.E. Bosworth (Oxford: Clarendon Press, 1974), 401-2.

${ }^{49}$ Makdisi, "Magisterium," 119, 126, 131. 
salah satu ciri sistem hukum modern di mana peran penguasa sangat kuat kurang mendapat tempat dalam pemikiran hukum Islam masa klasik dan tengah.5 Berdasarkan data sejarah, kodifikasi hukum Islam baru terjadi pada masa modern setelah adanya pengaruh sistem hukum sekuler Barat, dan hal itu dimulai dengan munculnya kitab Majallah al-Ahkam al-Adliyyah di Turki Utsmanis1 yang kemudian diteruskan dan disosialisasikan oleh Abd Razzaq Ahmad al-Sanhuri, seorang fuqaha dari Mesir dengan karya magnum opus-nya berjudul al-Wasit fi Sharh al-Qanun al-Madani alJadio $^{2}$

Akhirnya, setelah memahami konsep dan realitas supremasi hukum Islam dengan prinsip-prinsip yang ada di dalamnya, maka selanjutnya perlu ditelusuri apakah hal tersebut terealisasi secara baik di Indonesia, khususnya di kalangan umat Islam?

\section{Hukum Islam dan Masyarakat Madani di Indonesia}

Setelah Suharto lengser keprabon, rakyat semakin menyadari bahwa selama ini telah terjadi proses pembodohan umat secara sistematis, bukan saja selama Orde Baru tapi juga masa Orde Lama. Pemusatan kekuasaan dan kekuatan (centralization of power) yang disertai dengan penyalahgunaan (abuse of power) telah menjadi bahasa harian. Hukum dirumuskan bukan unfuk menegakkan kebenaran dan keadilan tapi justru untuk kepontingan melanggengkan kekuasaan sebagai sarana menumpuk kekayaan dan memenuhi ambisi individu maupun kelompok. Singkat kata: hukum tunduk kepada kekuasaan dan bukan sebaliknya, dan negara telah menjadimachtstaat dan bukan lagi rechtstaat.

Namun demikian, kekuasaan dan kekuatan yang "anti hukum" tersebut tidak mampu mematikan dan memadamkan se- mangat anti kekuasaan otoriter pada sebagian masyarakat. Berbagai cara mereka lakukan walaupun akhirnya berbenturan dengan tembok keras kekuasaan. Seperti digambarkan Hikam, ${ }^{53}$ sejumlah LSM, organisasi sosial dan keagamaan tetap berusaha menyuarakan suara-suara rakyat yang lemah dan tertindas (dlu afa wa almustadl'afin). Upaya-upaya ini ternyata tidak sia-sia dan pada akhirnya ikut andil melahirkan apa yang sekarang dikenal dengan Orde Reformasi, yaitu satu era dimana umat menuntut perubahan radikal pada seluruh aspek kehidupan, termasuk evaluasi terhadap peran hukum yang selama ini termarginalkan dalam negara kesatuan ini.

Dalam kondisi demikian tidak ada pilihan lain bagi institusi-institusi negara baik yang tergolong legislatif, eksekutif, yudikatif maupun institusi lain di tengahtengah masyarakat untuk mendukung ide

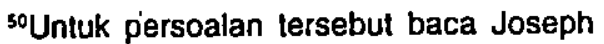
Schacht, "Problems of Modern Islamic Legislation." Studia Islamica 12 (1960), 99-129; Ann Elizabeth Mayer, "The Shariah: A Methodology or a Body of Substantive Rules?," dalam Islamic Law and Jurisprudence: Studies in Honor of Farhat J. Ziadeh, ed. Nicholas Heer (Washington: University of Washington Press, 1990), 177-98.

s'Baca Subli Mahmasani, Falsafah alTasyri' fi al-Islam (Beirut: Dar al-'llm lil-Malayin, 1961), 80-92. Untuk perkembangan hukum Islann di Turki Jan awal prosos mudernisasi hukum dalam Islam, baca Akh. Minhaji, "Islamic Law under the Ottoman Empire," dalam The Dynamics of Islamic Civilization (Yogyakarta: Titian Ilahi Press, 1997), 184-208.

${ }^{52}$ Kairo, 1952-1970. Karya lainnya berupa al-Qanun al-Madani: Majmu at al-A'mal alTahdiriyyah (Kairo: Ministry of Justice, t.t.).

53Hikam, Civil Society, terutama bagian ketiga. 
reformasi yang berusaha mewujudkan civil society atau masyarakat madani. Namun tidak jarang pula, individu maupun kelompok yang menjadi pendukung penguasa korup sebelumnya secara lantang meneriakkan reformasi, layaknya musang berbulu ayam atau maling teriak maling.

Melalui kepemimpinan Presiden Abdurrah man Wahid, misalnya, pemerintah Order Reformasi kali ini berusaha mewujudkan masyarakat yang menghormati hukum didukung oleh sikap-sikap pluralis, egaliter, demokratis, toleran, dan yang amat penting adalah percaya diri dan mandiri, yakni keyakinan dan kesiapan menyelesaikan persoalan-persoalan yang dihadapi tanpa banyak berharap bantuan pihak lain termasuk pemerintah. Bagi mereka yang menekuni pemikiran hukum Islam (fiqh), terutama tentang konsep jurists' law, lawyers' law, atau hukum fuqaha sebagaimana dijelaskan pada bagian sebelumnya maka amat mudah memahami pemikiran dan upaya Presiden tersebut. Sayangnya, keinginan Presiden ini belum bisa dipahami secara baik bukan hanya oleh rakyat awam tetapi juga oleh sebagian menteri atau aparat pemerintah lainnya yang terbiasa menunggu petunjuk atau pengarahan dari atasannya. Padahal, upaya Presiden itu tidak akan berhasil dengan baik jika tidak didukung oleh unsur-unsur lain, termasuk masyarakat itu sendiri. Dalam konteks inilah kita patut mencermati kondisi masyarakat yang ada, termasuk organisasi keagamaan yang di Indonesia ini cukup memainkan peran penting dalam kehidupan sehari-hari. Dalam bahasa sederhana: sejauhmana organisasi keagamaan mampu mendukung terciptanya masyarakat yang mempunyai kepercayaan diri dan sekaligus mandiri?

Sebagai contoh kasus, barangkali menarik bagi kita untuk mencermati organisasi Nahdlatul Ulama (NU), paling tidak karena tiga alasan. Pertama, NU adalah organisasi keagamaan yang tergolong besar, jika bukan yang terbesar, dengan pengikut yang tersebar hampir di seluruh penjuru tanah air. Kedua, Presiden sekarang ini berasal dari kalangan NU yang nampak masih mempertahankan tradisi ke-NU-annya. Dan ketiga, menurut pandangan Hikam, organisasi ini mempunyai peran penting dalam upaya mewujudkan masyarakat madani di Indonesia..$^{54}$

Tanpa menafikan peran-peran positif yang dimainkan NU, ternyata ada sejumlah tradisi di dalamnya yang perlu dicermati sehingga tidak kontra-produktif dalam upaya mewujudkan masyarakat madani dimana hukum menjadi panglima. Dari sudut pendidikan dan pengajaran di Pesantren, misalnya, model yang diterapkan lebih bersifat teacher oriented ketimbang library oriented. Model demikian sulit, bahkan tidak mungkin, untuk bisa melahirkan anak didik yang lebih berorintasi pada logic of discovery tetapi akan terjebak pada pola logic of justification bahkan logic of repeatation. Karena itu tariqat al-nazar atau munazarah. tradisi penting pada awal Islam, sulit dibayangkan, terutama antara teacher dengan students. Dengan sistem pendidikan dan pola pikir demikian maka wajar jika taqlid menjadi model utama sedangkan ijtihad merupakan sesuatu yang tabu bah. kan haram. Pola demikian sangat kondusif bagi cara pandang look backward ketimbang look forward. Akibat lanjut, sakralisasi terhadap pikiran-pikiran keagamaan masa lalu (taqdis al-alkar al-dini) tidak dapat dihindari (inevitable).

Di samping itu, loyalitas terhadap pernikir sebelumnya dan juga orang-orang yang dituakan tidak jarang melampaui batas-

\footnotetext{
s4 Ibid., 231-8.
} 
Topik: Supremasi Hukum dalam Masyarakat Madani..., Akh. Minhaji

batas kemanusiaan, dan kadangkala cenderung pada kultus individu. Ungkapanwali kemudian menjadi fenomena harian. Dan seorang pemimpin yang mendapat julukan wali menjadi kebal kritik dan harus dibela without any resenve.55 Dalam konteks kehidupan modern, pola kepemimpinan de mikian amat persoalan; ,sebab, kepemimpinannya tidak bisa diukur dan diuji berdasarkan standar yang secara transparan dipahami masyarakat luas. Dalam bahasa Kuntowidjojo, telah terjadi mistifikasi terhadap persoalan kehidupan yang sebenarnya amat profan (tadnisi, tajdibi).

Pola pandang di atas terlihat jelas pada pemikiran hukum Islam yang, seperti dijelaskan sebelumnya, merupakan inti ajaran Islam, dan dalam kenyataannya menempati posisi penting dalam pola hidup masyarakat NU. Dua tahun lalu, saya sudah mengkritik pola pemikiran hukum yang bercorak "tradisional" yang menolak nuansa-nuansa pemikiran baru di kalangan NU. ${ }^{56}$ Sebab, berdasarkan konstitusi yang ada, NU mendasarkan pemikiran hukumnya atas empat mazhab: Maliki, Hanafi, Syafi'i, dan Hanbali. Bahkan dalam praktek hanya membatasi diri pada mazhab Syafi'i, dan dalam hal demikian tidak ada bedanya dengan pemikiran hukum Perti. ${ }^{57}$ Itupun masih lebih dibatasi lagi dengan pemikiranpemikiran yang bernuansa Rafi'i. Di samping itu, pola pendekatan normatif yang bercirikan Aristotalian logic ${ }^{58}$ yang belakangan ini mendapat gugatan dan kritikan dari para ahli hukum Islam modern masih dominan di kalangan NU.9 Saya menunggu dengan penuh antusias hasil evaluasi dan modifikasi konstitusi NU yang dilakukan pada saat Mu'tamar di -Pondok Pesantren Lirboyo Kediri, Nopember 1999. Ternyata, evaluasi dan modifikasi, terutama menyangkut pola bermazhab, hanya menyentuh persoalan redaksional ketimbang persoalan substantif; sebab pola empat mazhab dan juga pola normatif tidak mengalami per- ubahan berarti.

Dengan model kajian hukum seperti di atas maka akibatnya bisa dibayangkan. Kajian hukum Islam di kalangan NU hanya mengulang-ulang pandangan metodologi hukum Islam (ushul al-figh, Islamic jurisprudence) dan juga rumusan-rumusan hukum (furu' al-fiqh, substantive law) yang

${ }^{55}$ Kasus Group Lawak Bagito merupakan contoh kongkrit dari fenomena di atas.

${ }^{56}$ Baca Minhaji, "Ahmad Hassan," terutama Bab 5 bagian $A$.

${ }^{57}$ Untuk konstitusi NU, baca Abubakar Atjeh, Sedjarah Hidup K.H.A. Wahid Hasjim dan Karangan Tersiar (Djakarta: n.p., 1957), 505, 509; Saifuddin Zuhri, Sejarah Kebangkitan Islam dan Perkembanganinya di Indo. nesia (Bandung: Maarif, 1981), 610; Mahmud Yunus, Sejarah Pendidikan Islam di Indonesia (Jakarta: Mutiara Sumber Widya, 1992), 240, 243.

${ }^{58}$ Aristotalian logic yang bercirikan dchotomous logic atau dalam bahasa John Dewey in pairs of dichotomies dikenal dengan pola eternalistic-absolutistic-spiritualistic-logic, yakni satu model kajian yang mendekati masalah secara hitam-putih, benar-salah, halalharam, dan yang semacamnya. Akibatnya. pemikiran yang ada bersifat sempit, rigid, kaku, dan menolak nuansa-nuansa di luar dua kutub ekstrem tersebut. Kebalikan dari pola pikir di atas adalah Hegelian logic yang bercirikan dialectical logic yang bersifat temporalistic-relativistic-materialistic-logic, yang of dalam Islam diperkenalkan pertama kali, menurut Taha Hussein, oleh Ibn Khaldun melalui "ilm al-'umran, the science of association, the science of civilization; baca Taha Hussein, Elude analytique at critique de la philosophie sociale d'lbn Khaldun (Paris: A Pedone, 1917), 202. Baca pula Fuad Baali dan Ali Wardi, Ibn Khaldun and Islamic Thought-Stayles: $A$ Social Perspective (Boston: G.K. Hall and Co., 1981).

${ }^{59}$ Baca Akh. Minhaji, "Orientasi Kajian Ushul Fiqh," alJami ah 63 (1999), 12-28. 
telah ada bahkan lahir pada beberapa abad sebelumnya. Dengan model pemikiran demikian maka sulit diharapkan untuk bisa mengkaji, apalagi menerima, kajian-kajian ushul al-fiqh modern yang dilahirkan, misalnya, oleh Mahmud Syaltut, ${ }^{\circ}$ Yusuf al-Qardlawi, ${ }^{61}$ Fazlur Rahman, ${ }^{62}$ Ali Syari'ati, ${ }^{63}$ Mahmud Muhammad Taha dan Abdullahi Ahmed An-Na'im, ${ }^{64}$ Hasan Hanafi, ${ }^{65}$ Nasr Hamid Abu Zayd, ${ }^{66}$ Mohammed Arkoun, ${ }_{1}^{67}$ dan yang terbaru Muhammad Syahrur. ${ }^{68}$ Bukan sekedar itu. Kalangan NU bukan hanya tidak akan terekspos dengan karyakarya dan pemikiran-pemikiran hukum baru, tapi juga sulit diharapkan lahirnya karyakarya dan pemikiran-pemikiran hukum baru dari kalangan NU sendiri.

Jika dicermati, tradisi NU di atas berbeda bahkan bertentangan dengan tradisi pada masa awal Islam terutama terkait dengan prinsip jurists' law, lawyers' law, atau hukum para fuqaha sebagaimana dijelaskan panjang lebar pada bagian sebelumnya. Barangkali menyadari semua ini maka nampak semakin banyak kalangan muda NU yang "terpaksa keluar" dari mainstream NU untuk bisa mengembangkan pikiranpikirannya, terutama bagi mereka setelah membaca karya-karya di luar kitab-kitab standar (mu'tabar) menurut NU dan juga setelah terekspos dengan model-model pendidikan modern yang lebih memberikan kesempatan untuk mengembangkan kemampuan intelektualnya. LKiS Yogyakarta dan eLSAD Surabaya merupakan dua contoh kongkrit dari fenomena dimaksud. Kedua pusat kajian keagamaan kalangan muda NU ini bukan hanya tidak lagi mengikatkan diri kepada empat mazhab hukum Islam sebagaimana aturan formal seperti tertuang pada konstitusi NU tetapi juga menjadikan karya-karya Istam di luar kalangan Sunni, seperti dari kalangan Syi'ah, bahkan luar kalangan Islam, seperti Karl Marx dan tokoh sosialis lainnya, sebagai bahan bacaan
${ }^{60}$ Baca karyanya al-Islam: Agidah wa Syari'ah (Mesir: Dar al-Qalam, tt.), dan analisa terhadap pemikirannya bisa dibaca pada Kate Zebiri, Mahmud Shaltut and Islamic Modernism (Oxford: Clarendon Press, 1993).

'Yusul al-Oardlawi, al-jitihad fi al-Shari'ah al-Islamiyyah Ma'a Nazarat Tahliliyyah fi allitihad al-Mu'asir (Kuwait: Dar. al-Qalam, t.t.).

${ }^{62}$ Analisa terbaru terhadap pemikiran Fazlur Rahman dapat dibaca dalam Earle $\mathrm{H}$. Waugh dan Frederick M. Denny, ed. The Shaping of an American Islamic Discourse: $A$ Memorial to Fazlur Rahman (Atlanta: Scholars Press, 1998).

${ }^{63}$ Ali Syari'ati, On the Sociology of Islam, terj. Hamid Algar (Berkeley: Mizan Press. 1979), terutama Bab II. "Approaches to the Understanding of Islam," 39-69.

${ }^{64}$ Konsep nasakh yang umum bisa dibaca dalam Muhammad Abu Zahrah, Ushul al-Figh (Beirut: Dar al-Fikr al-Arabi, 1958), 184-97. Sedangkan konsep nasakh baru baca Mah moud Muhammad Taha, The Second Mes. sage of Islam, terj. Abdullahi Ahmed An-Na'im (Syracuse: Syracuse University Press, 1987). Pikiran Toha ini kemudian dikembangkan lebih lanjut oleh muridnya bernama, An-Na'im, dan sernakin hari semakin mendapat perhatian kalangan ahli Islam; baca misalnya Abdullahi Ahmed An-Na'im, Toward an Islamic Reformation: Civil Liberties, Human Rights, and International Law (Syracuse: Syracuse University Press, 1990).

${ }^{65}$ Paling tidak dibaca Disertasinya yang berjudul Les Methodes d'Exegese, essai sur la science des fondaments de la comprehension, 'ilm usul al-figh.

${ }^{66}$ Nasr Hamid Abu Zayd, Malhum al-Nass: Dirasah fi 'Ulum al-Qur'an (Beirut: al-Markaz al-Saqafi al-Arabi, 1994).

${ }^{67}$ Baca Mohammed Arkoun, Rethinking islam: Common Questions, Uncommon Answers (Boulder: Westview Press, 1994).

${ }^{68}$ Baca Muhammad Shahrur, al-Kitab wa ak-Qur'an: Qira'ah Mu'asirah (Kairo: Sina litNashr, 1992); untuk analisa terhadap karya tersebut baca Wael B. Hallaq. A History of Islamic Legal Theory: An Introduction to Sunni Usul al-Figh (Cambridge: Cambridge University Press, 1997), 245-53. 
harian mereka. Ungkapan-ungkapan yang digunakan pun tidak jarang "murtad" dari tradisi NU. Untuk menyebut satu contoh, muncul sebuah karya, misalnya, berjudul Tuhan pun Lalu Tertawa. ${ }^{69}$

Tidak dapat dipungkiri bahwa walaupun kalangan muda NU tersebut sering dihujat oleh kelompok mainstream namun mereka secara berangsur-angsur dan pasti mulai menembus wacana-wacana kontemporer dan menempatkan dirinya pada kelompok pemikir modern yang tidak jarang justru berpikir lebih maju ketimbang pengikut organisasi keagamaan modem (mis. Persis atau Muhammadiyah). Di samping itu, kalangan old fashion dan mainstream NU semakin merasakan dampak gerakan kaum muda ini dan diantara mereka mulai memberikan perhatian bahkan dukungan walaupun seringkali secara diam-diam. Mungkinkah proses ini berjalan lebih cepat? wallu a lam. Namun, jika proses ini berjalan terus maka NU semakin lama semakin menjauh dari khittah 1926, terutama terkait dengan pola berpikir empat mazhab.

Analisa terhadap fenomena $\mathrm{NU}$ di atas sekaligus merupakan catatan penting bagi Hikam dan lainnya yang dalam karya-karyanya cenderung menempatkan NU (tanpa pemilahan secara jernih terhadap lapisanlapisan pengikutnya) pada posisi avant garde dalam gerakan mewujudkan masyarakat madani di Indonésia.

Selanjutnya, ada hal lain yang penting disampaikan di sini, terutama terkait dengan hukum di Indonesia. Hukum yang harus ditegakkan di Indonesia sebagai perwujudan masyarakat madani haruslah hukum yang berasal dari dan didasarkan atas ajaran agama. Sebab masyarakat madani, seperti ditegaskan Komaruddin Hidayat, adalah sama bahkan identik dengan masyarakat agama. ${ }^{70}$ Ini penting digarisbawahi mengingat hampir selama Orde Lama dan juga Orde Baru, hukum secara penuh didasarkan pada pemikiran hukum sekuler dimana agama dikesampingkan sedemikian rupa. Karena hukum agama tidak lagi dikaji secara transparan akibatnya hukum agama yang semula bertujuan mulia justru menjadi alat ampuh kaum provokator untuk memecah belah umat, bahkan tidak jarang menjadi justifikasi pelanggaran hak-hak asasi manusia (huquq al-insan al-asasiyyah, human rights). Saat ini, menjadikan hukum agama sebagai landasan hidup dan kehidupan umat telah menjadi ciri penting bagi masyarakat global yang ditandai dengan muncuInya era post-modernisme sebagai antitesis modernisme yang bercirikan sekuler?" Karena itu jangan heran jika nuansa keagamaan (sebagian menyebut religiositas atau spiritualitas) semakin menguat hampir di seluruh dunia termasuk di Indonesia. Dalam konteks ini munculnya sejumlah partai politik Islam, evaluasi dan modifikasi dasar dan asas NU pada saat Muktamar di Lirboyo, menggemanya ide perlunya penggantian asas Pancasila menjadi asas Islami pada' Kongres HMI di Jambi merupakan contoh-contoh yang amat signifikan. Arif Budiman tidak berlebihan ketika menggambarkan bahwa pertarungan politik yang terjadi antara kaum nasionalis yang dilambangkan dengan Mega dan kaum agama (Islam, santri) dengan representasi Gusdur (dan Amien Rais) pada akhirnya dimenangkan oleh kaum agama. ${ }^{72}$

${ }^{69}$ Machasin, ed. Tuhan pun Lalu Tertawa (Yogyakarta: LKiS, 1999).

${ }_{70}$ Komaruddin Hidayat, "Masyarakat Agama dan Agenda Penegakan Masyarakat Madani," dalam Membangun Masyarakat Madani, 267.

"Untuk gejala dan ciri post-modernism, baca Minhaji, "Reorientasi Kajian Ushul Fiqh," 12-28.

${ }^{72}$ Arif Budiman, "Rekonsiliasi ini Hanya Pragmatis Politik Saja," Media Indonesia (24 Oktober 1999), 4. 
Topik: Supremasi Hukum dalam Masyarakat Madani..., Akh. Minhaji

\section{Catatan Akhir}

Pemibahasan pada makalah ini telah menunjukkan bahwa masyarakat madani menjadi tuntutan semakin kuat di berbagai penjuru dunia, termasuk Indonesia. Dan supremasi hukum merupakan ciri penting, jjka bukan yang terpenting, suatu masyarakat madani; tanpa supremasi hukum tidak ada masyarakat madani.

Untuk konteks Indonesia, perlu dicatat bahwa sesuai dengan falsafah negara yakni Pancasila maka hukum harus didasarkan pada agama bukan pemikiran sekuler yang terbukti telah menghancurkan Indonesia selama masa Orde Lama dan Orde Baru. Hukum agama di sini diharapkan bersifat inklusif, dan hal ini bisa dibangun jika semua pihak terutama umat islam yang mayoritas mampu menghidupan kembali prinsip hukum Islam yang bersifat jurists'law, lawyers' law, atau hukum para fuqaha. Dengan cara ini maka diharapkan agar semua aspek kehidupan, terutama aspek pendidikan yang ada, memberi peluang cukup untuk bersemainya empat hal berikut: inter-faith sesitivities, gender sensitivities, social sensitivities, dan inter-group sensitivities.

Di samping itu, semua pihak termasuk yang terlibat dalam organisasi keagamaan mempunyai peran penting dalam upaya menegakkan supremasi hukum menuju terwujudnya masyarakat madani. Organisasi keagamaan perlu digarisbawahi di sini mengingat tidak semua tradisi yang ada di dalamnya cukup kondusif untuk mendukung terwujudnya supremasi hukum. Kondisi pemerintahan yang relatif kondusif untuk membangun masyarakat madani saat ini hendaknya dimanfaatkan secara bersamasama dan maksimal untuk mengerahkan segala upaya dan tenaga guna memperbaiki segala kesalahan fundamental yang terjadi selama bertahun-tahun di negeri ini. Dalam konteks ini maka upaya separa- tisme yang muncul di sebagian wilayah nusantara perlu dipertimbangkan kembali agar tidak terjebak pada penghianatan terhadap kommitmen bersama ketika membangun negara kesatuan seperti diikrarkan pada tahun 1928. Janganlah kesalahan yang dilakukan sejumlah penguasa Orde Lama dan Orde Baru melalui praktek KKN justru dijawab dengan kesalahan yang tidak kalah seriusnya, yakni tercerai-berainya negara kesatuan. $\square$

\section{Daftar Pustaka}

Muhammad AS Hikam, Demokrasi dan Civil Society (Jakarta: LP3ES, 1999).

Azyumardi Azra, Menuju Masyarakat Madani (Bandung: Remaja Rosdakarya, 1999).

Ahmad Baso, Civil Society versus Masyarakat Madani (Bandung: Pustaka Hidayah, 1999).

Akh. Minhaji, "Pendekatan Sejarah dalam Kajian Hukum Islam," Mukaddimah (forthcoming, Januari 2000).

Tilman Nagel, Rechtleitung und Kalifat: Versuch uber eine Grundfrage der islamishen Geschichte (Bonn: Bonnẹr orientalische Studien, 1975).

Patricia Crone dan Martin Hinds, God's Caliph: Religious Authority in the First Centuries of Islam (Cambridge: Cambridge University Press, 1986)

Patricia Crone, Slaves on Horses: The Evolution of the Islamic Polity (Cambridge: Cambridge University Press, 1980).

Muhammad Qasim Zaman, "The Caliph, The Ulama, and The Law: Defining the Role and Function of the Caliph in the Early 'Abbasid Period," Islamic Law and Society 4 (1997), 1-36. 
Topik: Supremasi Hukum dalam Masyarakat Madani..., Akh. Minhaji

Muhammad Benaboud, "Socio-Political Role of Andalusian Ulama during the Fifth/ Eleventh Century," Islamic Studies 30 (1991), 182.

Falur Rahman, "Islam and Political Action: Politics in the Service of Religion," dalam Cities of God, 154.

vine Law--Social and Human Norm," dalam Ideals and Realities of Islam (London: Allen \& Unwin, 1985).

Louis Marlow, "Kings, Prophets, and the Ulama in Medieval Islamic Advice Literature," Studia Islamica 81 (1995).

Seyyed Hossein Nasr, "The Shari'ah, Di- 